\title{
Five Facets of the Pentagon in the Convent of Toni Morrison's Paradise
}

\author{
R.M.Prabha \\ Ph.D. Scholar \\ ManonmaniamSundaranar University \\ Tirunelveli, Tamil Nadu \\ prabharmk@gmail.com
}

\begin{abstract}
Paradise is Toni Morrison's seventh novel and is published in the year 1997. The structure of the novel is complex involving many characters in the historical background of Afro-American black people. The novel describes the story of a black community in 1990s in Oklahoma. The novel also discusses the way in which the community built and lived in a town called Ruby. The town was near a convent, in which five women lived together. They were happy and free from any form of oppression from the community. The novel Paradise is all about the story of the dispute between these two communities. The five women of the convent are different from each other and reach the convent for diverse reasons. The women differ from each other in their thought, deed and actions. Analysis of their personality reveals their varied nature and interestingly their traits match well with the five different types of the 'Five Factor Model of Personality traits' of human beings. This paper analyses the personality of these five women and discusses the unique way in which Toni Morrison has crafted these characters in such a way that it fits unerringly with the five common traits of the Personality model of human beings.
\end{abstract}

Keywords: Five-factor model, personality, traits, convent, pentagon, facets.

\section{INTRODUCTION}

Researchers such as Lewis Goldberg, Naomi Take moto-Chock, Andrew Comrey, and John M. Digman did pioneering work on various traits of human personality. They formulated the five major traits in human personality. The five-factor model gained widespread acceptance among personality researchers during the 1980s [1]. According to them, all human beings in the world universally can be simply categorized in to five different Personality traits. Trait is defined as a temporally stable, crosssituational individual variance. The standard approach among various psychologists for studying personality traits is the Five-factor model or the Big Five dimensions of personality.

These five traits of human personality are also known as the "Big-Five." Peter Saville and his team coined the term "Pentagon" for this Five-factor model. The five factors that are included in this theory are defined as,

- Openness to experience,

- Conscientiousness,

- Extraversion,

- Agreeableness, and

- Neuroticism.

Five-factor model holds very well through most cultural and linguistic lines. Digman gives three examples of other cultures and languages in which the five-factor theory has worked nicely. Digman conducted three studies in Japan, Philippines, and Germany. In all three studies, the five-factor solution was clearly evident at the end of testing [2]. Digman found the subject of the ability of the five-factor model to cross cultural and linguistic barriers. He says, "... something quite fundamental is involved here. Is this the way people everywhere construe personality, regardless of language or culture?'[2]. The cross-cultural generalizability of the five-factor structure has been established through research in many other countries also [3]. Evidence also indicates that the Big Five traits are 


\section{R. M. Prabha}

heritable and stable over time [2, 3]. Hence the Five Factor Model can be applied to the women of the convent. Interesting observation is found when the five factor model is applied on to the inhabitants of the convent of Toni Morrison's paradise. The character analysis of the convent women was done and it revealed the fact that the convent women fell categorically into the five different components of the five factor model of McCrae and Costa.

\section{Convent}

Convent is a community, formed especially of nuns, bound by vows to a religious life under a superior. In the novel Paradise the convent was originally run by nuns. It is seventeen miles outside of the town Ruby. It is occupied by a group of women who had fled from their lives. Consequently the male citizens of the town begin to feel threatened. Because the Ruby men refused to allow any new ideas, beliefs, or ethnicities to interfere with their sense of racial pride and community, the Convent was seen as "dark and malevolently disconnected from God's earth" by them (Paradise, 18). The Convent women become the scapegoats for all the patriarchs of Ruby disintegrating in their Paradise of a town. Morrison says,

In white letters on a field of blue, a sign near the access road read CHRIST THE KING SCHOOL FOR NATIVE GIRLS. Maybe that was what everybody meant to call it, but in Consolata's living memory only the nuns used its proper name-mostly in prayer. Against all reason, the students, the state officials and those they encountered in town called it the Convent. (Paradise 233)

The Convent actually has never functioned as a convent. Initially, it was occupied by the embezzler as his hideaway and the Mansion displayed sensual status, pictures, and even bathroom fixtures. After the embezzler's arrest Mary Magna, the mother superior of a very small group of nuns, identifies the house as a Catholic run school for American Indian girls. With them is Connie, whom Mary Magna rescued from the streets of a South American city. The nuns do their best to annihilate the embezzler's indignity because it strikes them as explicit and appalling. As the government stops sending the funds, the nuns disperse. For some years, Mary Magna and Connie live alone in the Mansion. They support themselves by selling produced and baked goods for Ruby. Connie discovers within her a talent for mystic healing, and she keeps Mary Magna alive into advanced old age. Just before Mary Magna's death, they are joined by Maries Albrights the first of serious women who drift into the Convent. Gradually the community expands to Gigi (Grace), Seneca and Pallas True Love. The women have different personalities but similar experiences of men's indifferences and brutality.

\section{The Five Facets of the Pentagon}

Clinically, the five-factor model works much like Freud's psychoanalysis. People with a certain characteristic who falls at an extreme on the chart of one or more of the five variables are more likely to have some sort of psychological abnormality linked with that trait. People are likely to select their environment in such a way that this trait is perpetuated. To keep this cycle from recapitulating, psychologists make their patients come to terms with the flawed trait, allowing the patient to break the cycle [4].The five-factor model is more useful in research and learning than it is for psychological patients. To this end, supporters of the five-factor model point to the fact that factor analysis "serves as a useful bridge between the more clinical theories...and the learning, behavioral theories"[4]. The Big Five traits have been found to be pertinent and applicable to several aspects of life, such as subjective and personal well-being [5] and also longevity [6].

The NEO PI-R is a quantitative measure of the five major domains of personality under the main six facets that serves to define each domain. The five domain scales and thirty facet scales of the NEO PI$\mathrm{R}$ simplify a complete and detailed valuation of normal adult personality. The NEO PI-R is recognized internationally as a gold standard for personality assessment. The test was developed by Paul Costa, Jr. and Robert McCrae. A shortened version, the NEO Five-Factor Inventory (NEO-FFI) is a modification of the NEO PI-R model.

\subsection{Consolata (Connie) and Openness to Experience}

Individuals with this trait are said to have good appreciation for art, emotion, adventure, unusual ideas, curiosity, and variety of experience. Openness replicates the grade of intellectual curiosity, creativity and a predilection for novelty. It measures the tendency to fantasize. It reflects aesthetic sensitivity and the mindfulness and awareness of one's own emotions and preference for nontraditional values [7]. It is also described as the magnitude and extent to which a person is 
visionary and independent, and depicts a personal preference for a variety of activities over a strict routine. High openness can be perceived as unpredictability and lack of focus resulting in impulsive acts. Moreover, individuals with high openness are said to follow self-actualization particularly by seeking out intense and ecstatic experiences. Another important characteristic of the open cognitive style is the ability for thinking in symbols and concepts. Contrariwise, people with low openness pursue to gain contentment through stubbornness, and they are characterized as pragmatic and datadriven. They are sometimes even perceived to be dogmatic and closed-minded. The six sub-facets of this trait are fantasy, aesthetics, feelings, action, ideas and values.

In the novel Paradise, the character Consolata (Connie) is shown to have this trait of 'High Openness.' The way of her life and her thoughts correlate with this typical trait of human beings. She is one of the main characters of the novel. At a very early age she was sexually abused and was later rescued in Brazil at the age of eleven by Mary Magna. Mary eventually takes her to an Oklahoma convent, where she leads an unblemished life as a kind of servant. When she was thirty eight years old, she had a passionate love affair with Deacon Morgan. After long years of lone spiritual love, she was so ravenous for the love of a living man. Later he feels as if she wants to devour him. Disgusted, he ends the affair, and Consolata becomes an alcoholic.

After the visit of a mysterious stranger, she does not only succeed in overcoming her alcoholism, but also becomes a new strong kind of Mother Superior, a therapist who helps the other women come to terms with the traumatic experiences in their pasts. She becomes kind of a mystic healer. She learns a phenomenon known to be "stepping in" to the souls of dying people. By doing this she prolongs the life of Mary Magna. She also brings Scout into life after he dies in a car accident. The power of mystic healing and acceptance of such things shows her high imaginative tendency fantasizing unreal and non-traditional things. Connie is intellectually curious and has good receptivity to the inner world of imagination. When Deacon's son Scout is on the brink of dying after a car accident, Consolata gets him back to life by "stepping in" to his soul. Consalata as certains her supernatural talents. She gains "insight" into souls. However, she pays for this by gradually losing her eyesight. And by saving Scout she wins the friendship of his mother Soane. Hence, with her spiritual power she prolongs the life of her adored Mary Magna until 1970 and Scout.

Consolata is portrayed as a psychological and physical healer for the women in the convent. She is portrayed as a creator and healer who eventually becomes the leader of all the women. Creativity appears to be an important skill of effective leaders. According to Yukl, creativity was one of the abilities contained in summary of the skills of leaders [8]. This was based on the earlier review of Stogdillin 1974. Research indicates that creativity is linked to effective leadership [9]. And creativity is an important feature of the trait Openness. This suggests that open individuals have a huge potential to emerge as leaders and be effective leaders. Bass in 1990 listed the traits that were the best correlates of leadership and originality which is a clear hallmark of "Openness," surpassed the list [10].Consolata leads the women of the Convent to reconcile their fractured selves and heal their broken souls. She is hospitable and sociable and warmly welcomes each of the women into the Convent and readily offers them a place to stay. The only rule that Consolata imposes on her followers is that, "Lies not allowed in this place. In this place every true thing is okay" (Paradise 11). She instigates the preparation for the reconciliation and healing with a procedural 'Last Supper' for the women. The healing process begins through drawing templates and patterns on the floor of the basement. Consolata asks the women to lay on the flooring in a natural way. Then she draws around each one of the women. The women's templates and outlines become the cryptograms of their flesh. Appreciation for art and beauty is a prime feature of the trait Openness. Connie has a good appreciation for art and beauty which she transfers it to the women of the convent. The women start drawing patterns depicting the sufferings of the past and they speak their mind out through their diagrams on the floor and walls of the basement. By drawing such diagrams and patterns for days they feel emotionally relieved of their past tension, go in to a process of self-realization and soon become matured and content.

Consolata takes in all the stray women who come to the Convent, giving them shelter, help, and understanding without interrogating them or limiting their freedom. In the novel she is the one with the most inner strength. She is also a wonderful nurse, cook, and gardener. She is the leader of all the other women in the convent. She prepares the way for the destitute women of the convent and makes them comfortable. Good leadership also entails a surge of openness, since it allows leaders to be idealistic and to be able come up with operative solutions. In the last chapter Consolata, Connie says, 
If you want to be here you do what I say. Eat how I say. Sleep when I say. And I will teach you what you are hungry for. (...) If you have a place, (...) that you should be in and somebody who loves you waiting there, then go. If not stay here and follow me. Someone could want to meet you (Paradise 262).

Consolata is the effective leader for all the women in the convent. Connie has an incredible devotion for the nuns, specifically Mary Magna. She grows into adulthood with the nuns who vow that they will care for her always. Consolata had no fear except one. As she aged, the only thing she actually dreaded is that she will die alone. Initially Connie was living in the Convent with only the aged and bedridden Mary Magna. Later Mavis arrived and Consolata is relieved. She welcomes Mavis and exhibits her accepting and compliant nature in her indulgent attitude when Mavis says that her twins are living in the Convent with the women. This shows that she is open to inner feelings and emotions. Connie has a gift or magic power that allows her to see things that are not readily available to others. She is the first to say that Pallas is expecting a child. Connie has the gift of healing, though it is something she initially believes to be evil. Consolata is ready to re-examine her own values and those of authority figures. She questioned the healing powers and the provider Lone Du Pres. This again is an illustration for one of the behavioral facets of the trait 'Openness.' Moreover, Consolata is open to new experiences on a practical level. She promptly acts. She does not hesitate to act out the mystic power of stepping into the souls of dying people. In the end she is shot by her former lover's twin brother Steward Morgan in the raid on the Convent.

\subsection{Mavis Albrights and Conscientiousness}

People with the trait 'Conscientiousness' exhibit a high tendency to be organized and dependable. They show self-discipline, act dutifully, aim for achievement, and prefer planned rather than impulsive behavior. High conscientiousness is frequently perceived as tenacious and fanatical. People with low conscientiousness are bendable and extemporaneous, but can be perceived as sloppy and unreliable. The six facets of Conscientiousness are competence, order, dutifulness, achievement striving, self-discipline and deliberation.

Mavis accidentally lets her twins die of suffocation in a car while she is inside a grocery store buying wieners. Mavis feels guilt for allowing the deaths of her children though she denies that she was away for more than a few minutes and that guilt drives her to believe that her husband and remaining children are planning to kill her. This prompts Mavis to leave her family behind and she winds up at the convent where she settles in with Connie and lives for many years. Mavis is closer to Connie than the others though each of the women claims that Connie favors them. Mavis claims that her twins, Merle and Pearl, live in the Convent with the women. She says that she can tell by their voices and their laughter that they are growing older and this thought occupies a great deal of her time.

The character Mavis Albright in Paradise believes in own self efficacy. Though she is in a state of panic to run away from her abusive husband Frank, she does it efficiently. One early dawn she starts to flee and uses her husband's car the mint green Cadilla. She initially drives to her mother's house for maternal support. She stays at her mother's house for few days. She happens to overhear her mother revealing her location to Frank. She flees again from there. She paints her car magenta to avoid getting caught. She rides away, picks up hitchhiking women for company and for help with gas money. Later she lands up in the convent for borrowing gas when she meets Connie. Mavis in the novel is shown to be having good personal organization. In the convent she happens to see Gigi nude taking sun-bath. Mavis gets disturbed and compels Connie to send Gigi out. She even scolds and avoids Gigi for her shameless act. Mavis places emphasis on fulfilling moral obligations. She has good capacity to begin tasks and follow through to completion despite tiresomeness and interruptions. She aims for personal achievement and has a good sense of direction. Mavis has a high tendency to think things through before acting or speaking. Through this one can see the high conscientiousness trait in Mavis. Furthermore Mavis is a kind of emerging leader in the convent. She is the oldest of the four women who came to the convent. Her maturity and orderliness promote her to the possibility of being an emerging leader next only to Consolata. Persistence and determination are indicators of Conscientiousness [11] which are characteristic of Mavis. Mavis in the novel is also shown to be mindful of earning some money to help all the convent women. To Consolata, "Mavis talked endlessly of surefire money making ventures: beehives; something called "bed and breakfast"; a catering company; an orphanage" (Paradise 227). This shows her 'achievement striving,' quality which is a feature of Conscientiousness. She takes pride in being dutiful, as she says to Gigi, once "Whatever it is, it's my responsibility" (Paradise 176). 
Mavis preferred to stay in the convent as she perceives the voices of her kids there. In the convent, Mavis is also certain that Arnette's child, the boy who died soon after his premature birth, was with Merle and Pearl. Mavis spends most of her life afraid of arrest for having killed her twins. She believes that her husband is searching for her and that there's an arrest warrant out for her, both which make her unwilling to go back and seek out her remaining three children, even though she puts herself in a position to be able to see them at school. Conscientiousness is directly related to leader emergence. However leadership effectiveness has strong direct correlation with the trait Openness than with Conscientiousness. Mavis was the next possible and most probable leader for all the women in the convent. Mavis has high probability to be an emerging leader though may not be as effective as Consolata. She is the second oldest in the convent and showed signs to be a good associate for the actual leader Consolata. Mavis gets bullied often by Gigi with low Conscientiousness.

\subsection{Grace (Gigi) and Extraversion}

Extraversion represents the tendency to be sociable, assertive, active and to experience positive affects, such as energy and zeal. People who are extraverts have high energy, positive emotions, surgency, boldness, sociability and the tendency to pursue stimulation in the company of others. They are talkative and friendly. On the contrary, low extraversion causes a reserved and reflective personality which can be perceived as detached and self-absorbed. The six sub-facets of this trait include the warmth, gregariousness, assertiveness, activity, excitement Seeking and positive Emotions.

Gigi has a tendency to experience positive emotions. Toni Morrison says, definitely "Gigi was not the crying type" (Paradise 266). She prefers to be in company with others and has good social ascendancy and forcefulness of expression. She has an inner felt need for environmental stimulation. Gigi puts on a show of being extremely wild and attracts the attention of all the young men in town upon her arrival. This shows her interest in and friendliness towards others. Gigi's pace of living is swift. Gigi is looking for a mountain that looks like a pair of lovers locked in an embrace. It was described to her by her boyfriend, a man named Mikey who is now in jail but who told Gigi about the mountain and promised to meet her there after his release. It does not take Gigi very long to decipher that Mikey had been lying to her and she is faced with several options, including returning to the city near the jail where she had lived and worked and there to wait for Mikey's release. As she is trying to make up her mind what to do, she discovers that there is no hotel in Ruby and starts looking for a ride to a town where she can catch some form of public transportation. Roger Best offers to give her a ride in his van and she accepts. It is only after they are on their way that she learns that the van is a hearse and that he is going to pick up a body at the Convent. The old woman there has died and he warns Gigi that he is going to stop only for the few minutes it takes to load the body. He says that he has to meet a train to transport the body and that he will therefore be in a hurry. Gigi says she understands and tries to persuade herself that riding in the van with a dead body would not be a problem, though she is obviously upset by the thought.

However Gigi meets Connie in the convent and spends only a small amount of time with her. She easily gets acquainted to her in the brief time she had. She learns about the convent and the two women there. Mavis had been out of the convent for a while, when Gigi arrives in the convent. Gigi prefers to stay with Connie rather than to go with Roger Best. The quality 'extraversion' in Gigi allows her to become friends with anyone so readily. Her sociability is high. Moreover when the other two women Pallas True Love and Seneca arrive at the convent, she shows warmth and becomes friendly towards them. She is also an assertive woman who does not take much time to arrive at decisions.

High extraversion is frequently perceived as attention-seeking and authoritarian. Gigi in Paradise is found to show the most attention seeking with exhibitionistic attitude. She has a habit of taking sun bath nude without worrying about others around her. Mavis in fact, once calls her, "Exhibitionist bitch...God, I hate your guts." (p 176) revealing her assertive and exhibitionistic attitude. Gigi is portrayed as a woman who cares much about her appearance and style which she carries along. She is also shown to be a chain smoker and drug abuser. Once as gigi, "lit a fresh cigarette from a dying one, "Mavis could not bear it anymore and says, "Can't you stop smoking for two minutes?"(Paradise 175). Research has shown that smokers and drug abusers to score less on Conscientiousness [12]. Hence, Mavis with high conscientiousness is intolerable to the chain smoking, carefree attitude of Gigi. In many large-scale studies, smoking has been found to be associated either with extra version 


\section{R. M. Prabha}

or anxiety [13]. Smokers are found to have inability to resist cravings (high Impulsiveness). They search for stimulation (high Excitement-seeking). They lack of perseverance (low Self-Discipline) and lack careful consideration of the consequences of their actions (low Deliberation) [14]. Gigi is excitement seeking, impulsive which are traits of 'High Extraversion.' She has low self-discipline and low deliberation which could be explained by the fact that she scores less on conscientiousness unlike Mavis whom she has constant fights with.

\subsection{Pallas Truelove and Agreeableness}

Agreeableness is the propensity to be sympathetic and obliging rather than doubtful and hostile towards others. Altruism, diplomacy, and sensitivity are hallmarks of an agreeable personality. It is a measure of one's credulous and supportive nature. It shows whether a person is generally welltempered or not. High agreeableness is frequently seen as naive or submissive. Low agreeableness personalities are often perceived as competitive or challenging people. They can be seen as belligerent and undependable. Also, agreeable individuals are likely to be modest [15]. Research indicates that people high in agreeableness have more propensities to control negative emotions like anger in conflict situations. Those who are high in agreeableness are more likely to use conflict-avoidant tactics when in conflict with others. Conversely people with low agreeableness are more likely to use coercive and intimidating strategies. Highly agreeable people seem to be prepared to give ground to their opponent and may lose arguments with people who are less agreeable. However, from their perspective, they have not actually lost an argument as much as maintained a congenial relationship with another person.

In the novel Paradise, the character Pallas Truelove is shown to be modest and submissive which are main components of the personality 'Agreeableness.' Pallas Truelove is portrayed as a young girl who is abandoned by her mother in her childhood. She is brought up by her affluent, yet in-attentive father. She starts a relationship and runs away with an artist who works at her school. The two go to her mother's house where the young man and Pallas's mother are soon engaged in an affair. Pallas is heartbroken and runs away, eventually winding up at the Convent. She is devastated by grief upon her arrival and doesn't talk at all for some time. This shows her tender-mindedness. According to the modern NEO PI-R, the six facets of agreeableness are: Trust, straightforwardness, Altruism, Compliance, Modesty, and Tender-Mindedness. Pallas trusted her boyfriend and mother though was disappointed later. According to Gloria Robertson, "Pallas foolishly trusted Dee Dee Truelove, the absentee mother who mailed holiday greetings from afar while dismissing the responsibility of motherhood" [16].She was unselfish and compliant unlike her selfish mother and boyfriend Carlos.

Pallas in a state of panic fled her house behind the wheels of an automobile; she lost all sense of caution (Paradise 168). Her car wrecks and she gets attacked by men who chase her into a lake and rape her. Then she was taken to a clinic and later comes to the convent. Connie realizes immediately that Pallas is pregnant though Pallas herself doesn't realize it for some time. Pallas in the novel is a true illustration to have high Agreeableness. She is shown to be modest, trusting and tender-minded. She is straight forward as she is intimidated by the behavior of her boyfriend and leaves him straight away. She is compliant as she immediately accepts Connie in the convent who later succeeds in healing her fractured self. Though she is pregnant with an affair that has become un-wanted now, she agrees to carry the child. She does not try to abort or kill the fetus. She simply delivers a baby boy and names him Divine. This unwanted child may not be accepted by other people with low agreeableness. However the agreeable nature of Pallas Truelove allows her to accept things as it is. On the contrary, there was another character, Arnette Fleetwood in the novel, aborts a pregnancy which she considered 'unwanted.' She may be a person with low agreeableness.

\subsection{Seneca and Neuroticism}

Individuals with high score for Neuroticism have the tendency to experience unpleasant emotions easily. Emotions such as anger, anxiety, depression and vulnerability are easily felt by such individuals. Neuroticism also refers to high degree of emotional instability. Neuroticism represents the tendency to display poor emotional adjustment and experience negative affects, such as anxiety, insecurity, and hostility. Evidence also indicates that neurotic individuals are less likely to be perceived as leaders [17]. Hence, Neuroticism is negatively related to leader emergence and leadership effectiveness. The six facets of Neuroticism are anxiety, angry hostility, depression, selfconsciousness, impulsiveness and vulnerability. 
In the novel Paradise the character Seneca has a tendency to score high on neuroticism. Seneca is portrayed in the novel as a twenty years old woman. Seneca has great compassion for everyone else but herself. Seneca is left alone by her mother when she was five and she has no house or family. When Seneca's very young mother Jean abandons her, five year-old Seneca feels that may be it was her fault. She is passive and is raised with the idea that her purpose in life is simply to please other people. Before joining the convent women, she was picked up by a wealthy woman, and made to live as a prostitute for three months. An abused foster child, she mutilates herself by way of punishing herself for attracting men's attention. According to the psychologist Karen Horney, Neurosis is transmitted to a child from his or her early environment and that there are several ways in which this can happen. She says, "When summarized, they all boil down to the fact that the people in the environment are too wrapped up in their own neuroses to be able to love the child, or even to conceive of him as the particular individual he is; their attitudes toward him are determined by their own neurotic needs and responses" [18].

The child's initial reality is then distorted by his or her parents' needs and pretenses. Growing up with neurotic and disturbed caretakers, the child rapidly becomes insecure and develops basic anxiety. To deal with this anxiety, the child's imagination creates an idealized self-image. According to Karen Horney,

Each person builds up his personal idealized image from the materials of his own special experiences, his earlier fantasies, his particular needs, and also his given faculties. If it were not for the personal character of the image, he would not attain a feeling of identity and unity. He idealizes, to begin with, his particular "solution" of his basic conflict: compliance becomes goodness, love, saintliness; aggressiveness becomes strength, leadership, heroism, omnipotence; aloofness becomes wisdom, self-sufficiency, independence. What-according to his particular solution - appear as shortcomings or flaws are always dimmed out or retouched [18].

Seneca's neurotic behavior is the result of her mother's act of abandoning her at a very early age and early childhood sexual abuse by her foster brother. She was not given any time to go through the process of self-realization that could give a positive advance in her development of Personality. Seneca has a high level of free floating anxiety. She has great tendency to experience anger and related states such as frustration and bitterness. Her tendency to experience feelings of guilt, sadness, despondency and loneliness is also high. She is shy with social anxiety. She tries to act on cravings and urges rather than reining them in and delaying gratification. Seneca's general susceptibility to stress is high. Though Connie is also parentless and was abused sexually as a child, later she gets some comfort and protection from Mary Magna which helps her to build her personality stronger than Seneca. Seneca responds to all violence in such a way that she was responsible for it. To somehow make up for the political murders of Kennedy and King, she slits herself with razors. Seneca, "was secretly slicing her thighs, her arms. Wishing to be the queen of scars, she made thin red slits in her skin with whatever came to hand: razor, safety pin, paring knife" (Paradise 227).She wears longsleeved shirts and rousers to keep her scarred flesh hidden. Seneca's self-harming behavior correlates with her neurotic personality. Research indicates the high prevalence of self-harming instincts among Borderline Personality Disorders (BPDs) [19]. Personality disorders have a strong association with absurd environment. Unlike the two women in Toni Morrison's novel Sula, Sula Peace and Eva Peace, Seneca is truly neurotic and her self-injuring act has a definite psychological basis. In the novel Sula, Toni Morrison portrays Eva and Sula who are not neurotic in any form. Yet they indulge in selfharming activities. These women are different from Seneca of Paradise. In the convent, Seneca gets comfort and gets relieved from the constant abuse of the society. The constant abuse that created havoc in her maturing mind is replaced by a soft and soothing environment in the convent. Moreover the healing rituals of Consolata kind of give her a documented turning point in her life. She becomes more matured. Her self-injuring behavior changes and she becomes attached to the women of the convent. Seneca is particularly kind to Pallas.

\section{Conclusion}

Mavis and other women come to the convent, in search for freedom, love, peace, parental care and attention. They escape from a customary patriarchal society to find themselves, their own haven and shelter. In the convent, all of them are free. They readily accept anyone, irrespective of color or race. They help each other to live in peace. They are even free to leave at any time. The convent women choose to live their lives there. The women of the Convent do not possess any ideals of family or 


\section{R. M. Prabha}

society in their nomadic drifting. They tackle the anxiety of belonging and create an open house by challenging the social and historical structures that surround them and by challenging the daunting things inside themselves.

To create such an atmosphere in the Convent, Morrison uses five characters. She brings them from various places and amalgamates them together to give a unique taste of the Convent to the readers. Toni Morrison has crafted her characters splendidly in a diverse mosaic form as they fit precisely to the five facets of the Pentagon of Human Personality traits. Her structural organization is complete with these five characters. Consolata, the creator, healer and effective leader shows high openness to experience. The conscientious Mavis, agreeable Pallas, extravert Gigi and the neurotic Seneca are effectively lead by Consolata in the convent. The varied appearance of the five women in the convent is exact and defined intensely. Toni Morrison has meticulously crafted and sketched these characters as they are in one way or the other different from each other in their personality. Their personality matches well with the five items of the Five-factor model of personality traits.

\section{REFERENCES}

\section{Primary Source}

Morrison, Toni. Paradise. New York: Plume, 1999. Print.

\section{Secondary source}

[1] Goldberg, L. R. (1993). "The structure of phenotypic personality traits". American Psychologist 48: 26-34. doi:10.1037/0003-066x.48.1.26. Print.

[2] Digman, J.M. (1990). "Personality structure: Emergence of the five-factor model". Annual Review of Psychology 41: 417-440. Print.

[3] Costa, P.T.,Jr. \& McCrae, R.R. (1992). Revised NEO Personality Inventory (NEO-PI-R) and NEO Five-Factor Inventory (NEO-FFI) manual. Odessa, FL: Psychological Assessment Resources. Print.

[4] Pervin, L. A. (1989). Personality: Theory and research (5th ed.). New York: Wiley. 1989 Print.

[5] DeNeve, K. M., \& Cooper, H. (1998). "The happy personality: A metaanalysis of 13 personality traits and subjective well-being." Psychological Bulletin, 124, 197-229. Print.

[6] Friedman, H. S. et al.,(1995). "Childhood conscientiousness and longevity: Health behaviors and cause of death." Journal of Personality and Social Psychology, 68, 696-703. Print.

[7] McCrae, R. R., Costa, P. T. (2003). Personality in adulthood, a five-factor theory perspective (2nd ed.). New York: Guilford Press. Print.

[8] Yukl, G., \& Van Fleet, D. D. (1992). "Theory and research on leadership in organizations." In M. D. Dunnette\& L. M. Hough (Eds.), Handbook of industrial and organizational psychology (Vol. 3, pp. 147-197). Palo Alto, CA: Consulting Psychologists Press. Print.

[9] Stogdill, R. M. (1974). Handbook of leadership. New York: Free Press. Print.

[10] Bass, B. M. (1990). Bass and Stogdill's handbook of leadership. New York: Free Press. Print.

[11] Costa, P. T., Jr., et al., (1991). Facet scales for agreeableness and conscientiousness: A revision of the NEO Personality Inventory. Personality and Individual Differences, 12, 887-898. Print.

[12] Antonio Terracciano et al., "Five-Factor Model personality profiles of drug users." $B M C$ Psychiatry, 2008, 8:22. Print.

[13] McCrae RR, et al.,"Anxiety, extraversion and smoking."British Journal of Social \& Clinical Psychology. 1978;17:269-273. Print.

[14] Terracciano Antonio and Paul T. Costa Jr."Smoking and the Five-Factor Model of Personality."Addiction. 2004 Apr; 99(4): 472-481.Print.

[15] Goldberg, L. R. (1990). An alternative "description of personality": The Big-Five factor structure. Journal of Personality and Social Psychology, 59, 1216-1229. Print.

[16] Roberson, Gloria. The World of Toni Morrison: A Guide to Characters and Places in Her Novels. London: Greenwood Publishing Group, 2003. Print.

[17] Hogan, R., Curphy, G. J., \& Hogan, J. (1994). What we know about leadership: Effectiveness and personality. American Psychologist, 49, 493-504. Print.

[18] Horney, Karen (1950). Neurosis and Human Growth: The Struggle toward Self-Realization. W.W. Norton \& Company, Inc. Print.

[19] Niedtfeld I,et al., (2010). Affect regulation and pain in borderline personality disorder: a possible link to the understanding of self-injury. Biological psychiatry, 68 (4), 383-91 PMID: 


\section{AUTHOR'S BIOGRAPHY}

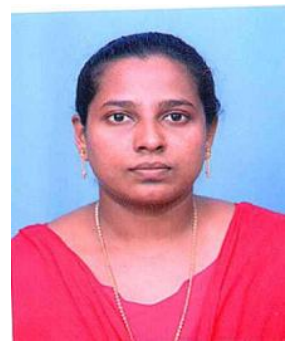

R.M. Prabha, is a research scholar, currently pursuing her Ph.D. course at the Manonmaniam Sundaranar University in Tirunelveli. Her main area of interest is Afro-American literature. She has extensively done research on the author Toni Morrison and her novels. She completed her under graduate [B.A English] degree course at the Govindammal Aditanar College for Women in Tiruchendur in 2006. She did her Master's degree in English [M.A] and subsequently M.Phil degree in Sarah Tucker College for Women in Tirunelveli. After her graduation she has served the college in which she did her undergraduate degree, as a faculty, Assistant Professor in English for nearly four years. Her project for her M.Phil degree was on the novel Jazz by Toni Morrison. Her current research work also involves Toni Morrison's select novels. 